\title{
CRAMBE CAKE (Crambe abyssinica hochst) ON LAMB DIETS
}

\author{
Torta de Crambe (Crambe abyssinica hochst) na alimentação de cordeiros
}

\author{
Érika Breda Canova ${ }^{1}$, Mauro Sartori Bueno ${ }^{2}$, Heverton Luis Moreira², \\ Rosana Possenti², Patrícia Brás ${ }^{2}$
}

\begin{abstract}
The use of alternative feedstuffs in animal diet, such as residues derived from the biodiesel production aims to increase productivity and reduce costs in animal production. Them aim of this study was to evaluate the substitution effect of $0,22,44$ and $64 \%$ of soybean meal protein by Crambe cake (Crambe abyssinica Hochst) protein in lamb diet. In the in vivo experiment, 20 lambs were used and evaluated the apparent digestibility, nitrogen balance and voluntary DM intake. The replacement of the protein resulted in a linear decrease in apparent digestibility coefficient (ADC) of dry matter (DM), organic matter (OM), ether extract (EE), gross energy (GE), acid detergent fiber (ADF), neutral detergent fiber (NDF), cellulose (CEL) and the percentage of total digestible nutrients (TDN), which resulted in decreased daily DM intake. The blood level of urea, glucose, alanine aminotransferase (ALT) and aspartate aminotransferase (AST) were not affected. In vitro gas production technique (GP) evaluation of diets showed a significantly decrease $(\mathrm{P}<0.05)$ of the total gas and methane production without altering the true degradability of $\mathrm{DM}$ and $\mathrm{OM}$ and the partition factor (PF). Replacement of soybean meal protein by the Crambe cake protein decreased digestibility of the fiber fraction of the diet, the voluntary intake of DM and methane, without altering rumen fermentation. Crambe cake can be utilized as lamb's food, because, despite reduced intake, assure a large energy intake and similarity to soybean meal protein.
\end{abstract}

Index terms: Co-product, digestibility, enteric methane, sheep, sustainability.

\begin{abstract}
RESUMO
A utilização de alimentos alternativos na dieta animal, como os resíduos da produção de biodiesel, tem como finalidade aumentar a produtividade e reduzir os custos na produção animal. Com esse intuito, objetivou-se avaliar o efeito da substituição de $0,22,44$ e $64 \%$ da proteína do farelo de soja pela proteína da torta de Crambe (Crambe abyssinica hochst) em dieta de cordeiros. No experimento in vivo, foram utilizados 20 cordeiros e avaliados a digestibilidade aparente, o balanço de nitrogênio e o consumo voluntário. A substituição da proteína resultou na diminuição linear do coeficiente de digestibilidade aparente (CDA) da matéria seca (MS), matéria orgânica (MO), extrato etéreo (EE), energia bruta (EB), fibra em detergente ácido (FDA), fibra em detergente neutro (FDN), celulose (CEL) e valor de nutrientes digestíveis totais (NDT), o que acarretou na diminuição do consumo diário da MS. Parâmetros sanguíneos de ureia, glicose, AST e ALT não foram afetados. No experimento in vitro, pela técnica semiautomática de produção de gás $(\mathrm{PG})$, houve diminuição significativa $(\mathrm{P}<0,05)$ da produção total de gás e produção de metano, sem alterar a degradabilidade verdadeira da MS e MO e o fator de partição (FP). A substituição das proteínas na dieta de cordeiros acarretou diminuição da digestibilidade da fração fibrosa da dieta, do consumo voluntario da MS e de metano, sem alterar a fermentação ruminal. A torta de Crambe pode ser utilizada na alimentação de cordeiros, pois apesar da diminuição do consumo de MS, garantiu grande aporte energético e a utilização da proteína na dieta foi similar ao farelo de soja.
\end{abstract}

Termos para indexação: Coproduto, digestibilidade, metano entérico, ovinos, sustentabilidade.

\section{INTRODUCTION}

Crambe is a plant of the Mediterranean and has been cultivated in South America, mainly as second harvest crop or for ground cover. Crambe cake is a protein ingredient derived from the extraction of seed oil by pressing, and has a variable amount of residual oil. The cake can be fed to ruminants because it may presents antinutritional factors glucosinolate, which hinder its use in monogastrics and can cause liver damage, reduced palatability, decreased growth, decreased production, and weight loss (Tripathi; Mishra, 2007).
The Crambe cake has a high lipid content in excess which can present a deleterious effect on the digestibility of some nutrients (NRC, 2007), yet, it may be a beneficial factor for enviroment, since it can help in mitigating the enteric methane (Abdalla et al., 2008). According to Grainger (2008) for every $1 \%$ increasing in fat on the diet of dairy cattle, the amount of methane produced per kg of ingested dry matter may be reduced in up to $6 \%$.

Crambe seeds have coats with high content of lignified fiber, which remains on the cake after the extraction of oil. The high content of lignified fiber can

\footnotetext{
1'Instituto de Zootecnia/IZ - Rua Heitor Penteado, 56 - Centro - 13460-000 - Nova Odessa - SP - Brasil - ecanova@cena.usp.br ${ }^{2}$ Instituto de Zootecnia/IZ - 13460-000 - Nova Odessa - SP - Brasil

Received in july 25, 2014 and approved in september 29, 2014
} 
reduce its utilization for lambs, which was evidenced by Steg, Hindle and Liu (1994) that showed reduced in vitro digestibility of Crambe meal with seed coat compared to without coat.

The oil extraction by cold pressing results in variable and often high EE cake. Lipids in ruminant diet is source of energy to animal, but is not used as a source of energy to rumen microbes and can reduce the enteric methane production (Abdalla et al., 2008), as well as, it can reduce fiber digestibility (Van Soest, 1994).

There are some techniques to evaluating ruminant diets, including in vivo apparent digestibility. This methodology evaluate the use of nutrients in the digestive tract of animals, through the balance of nutrient intake and fecal excretion (Van Soest, 1994). The in vitro gas production is used to measure gas production in the specific time period, true organic matter degradability and estimate microbial mass (Abdalla et al., 2007).

The aim of this study was to evaluate the replacement of soybean meal protein for Crambe cake protein by in vivo apparent digestibility, blood levels of glucose, urea, alanine aminotransferase (ALT), aspartate aminotransferase (AST) and the in vitro gas production.

\section{MATERIAL AND METHODS}

The experiment in vivo digestibility was conducted at the Instituto de Zootecnia (IZ/APTA/SAA) in Nova Odessa/São Paulo/Brazil. 20 wool lambs were used, with an average initial weight of $22.6 \pm 3.6 \mathrm{~kg}$, and ages of 120 days, assigned in randomized blocks by initial live weight. The diet was formulated to meet the nutritional requirements of late maturity lambs (degree of maturity 0.3 ) with live weight gain around $150 \mathrm{~g}$ per day (NRC, 2007).

The lambs were maintained on diets composed of grass hay and concentrate in the proportion of 30:70. The concentrate was formulated with ground corn, soybean meal and/or Crambe cake, mineral mixture and limestone. The replacement of soybean meal protein by Crambe cake protein were: $0,22,44$ and $64 \%$ (Table 1).

The table 2 shows the values of the chemical composition of the diets. At the beginning of the experiment was attempted to replace $100 \%$ of the protein of soybean protein by Crambe cake, however the animals did not consume the feed, therefore it was necessary to decrease the maximum percentage for $64 \%$ replacement.

In the experimental period, the animals were kept in metabolism cages, provided with individual feeders and collectors and separators of feces and urine. The experiment lasted 34 days, with a fortnight's adaptation, ten days of measurement of voluntary intake of DM and nine days for total feces and urine collection. On the voluntary intake measurement period, the amount of food offered was calculated to ensure leftovers around $20 \%$. On the feces and urine collection period, the amount of diet was restricted to $90 \%$ of the average consumption of the previous phase, aiming to restrict the selection and ensure total diet intake by the animal and taken to the measurement of apparent digestibility coefficients (ADCs) of DM, OM, CP, NDF, ADF, EE , GE, NFC, HEM and CEL and nitrogen balance (NBal).

Table 1 - Proportion of diet ingredients with increasing levels of replacement of soybean meal protein by Crambe cake protein.

\begin{tabular}{ccccc}
\hline & \multicolumn{4}{c}{ Levels of protein replacement (\%) } \\
\cline { 2 - 4 } Ingredients & 0 & 22 & 44 & 64 \\
\cline { 2 - 4 } & 30 & 30 & 30 & 30 \\
\cline { 2 - 4 } Hay grass & 51.1 & 47.3 & 43.5 & 39.8 \\
Corn & 16.1 & 13.2 & 9.8 & 6.4 \\
Soybean meal & 0.0 & 6.7 & 13.9 & 21.0 \\
Crambe cake & 1.1 & 1.1 & 1.1 & 1.1 \\
Mineral mixture* & 1.8 & 1.8 & 1.8 & 1.8 \\
Limestone & & \multicolumn{4}{c}{ Proportion of ingredients (\%) } \\
\hline
\end{tabular}

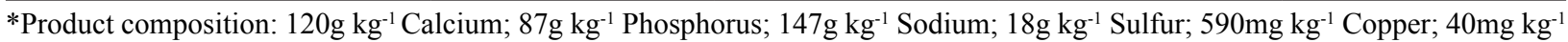
Cobalt; $20 \mathrm{mg} \mathrm{kg}^{-1}$ Chrome; $1.800 \mathrm{mg} \mathrm{kg}^{-1}$ Iron; $80 \mathrm{mg} \mathrm{kg}^{-1}$ Iodine; $1.300 \mathrm{mg} \mathrm{kg}^{-1}$ Manganese; $15 \mathrm{mg} \mathrm{kg}^{-1}$ Selenium; $3.800 \mathrm{mg} \mathrm{kg}^{-1} \mathrm{Zinc}$; $300 \mathrm{mg} \mathrm{kg}^{-1}$ Molybdenum; $870 \mathrm{mg} \mathrm{kg}^{-1}$ Fluorine.

Ciênc. Agrotec., Lavras, v.39, n.1, p.75-81, jan./fev., 2015 
Table 2 - Chemical composition of the diets, Crambe cake and hay grass.

\begin{tabular}{crrrrrr}
\hline \multirow{2}{*}{ Chemical composition } & \multicolumn{3}{c}{ Levels of protein replacement (\%) } & Crambe cake & Hay grass \\
\cline { 2 - 5 } & \multicolumn{1}{c}{0} & \multicolumn{1}{c}{22} & \multicolumn{1}{c}{44} & 64 & & \\
\hline DM (\%) & 85.32 & 86.28 & 87.025 & 86.99 & 87.50 & 88.04 \\
OM (\%) & 94.72 & 94.42 & 95.02 & 94.61 & 94.53 & 93.80 \\
CP (\%) & 16.78 & 15.72 & 16.83 & 16.53 & 24.67 & 8.65 \\
EE (\%) & 1.70 & 3.55 & 5.36 & 7.36 & 29.60 & 1.16 \\
NDF (\%) & 40.40 & 40.55 & 44.442 & 45.23 & 29.34 & 81.15 \\
ADF (\%) & 16.80 & 17.10 & 17.852 & 20.20 & 21.54 & 41.26 \\
ASH (\%) & 5.28 & 5.58 & 4.98 & 5.38 & 94.53 & 6.20 \\
CEL (\%) & 14.08 & 14.01 & 14.35 & 15.76 & 12.82 & 34.15 \\
HEM (\%) & 23.60 & 23.45 & 26.60 & 25.04 & 7.80 & 39.89 \\
LIG (\%) & 2.28 & 2.48 & 2.92 & 3.89 & 8.74 & 5.29 \\
NFC* (\%) & 35.84 & 34.606 & 28.39 & 25.49 & 10.92 & 2.84 \\
Gross energy (cal/g) & 4263 & 4306 & 4406 & 4531 & 5994 & 4264 \\
\hline
\end{tabular}

*NFC $=$ non-fibrous carbohydrate.

On the last day of the experimental period animals' blood samples were drawn with vacuum tubes with anticoagulant (heparin sodium) for measurements of concentrations of alanine aminotransferase (ALT), aspartate aminotransferase (AST), glucose and urea by the method of Kaneko, Harvey and Bruss (2008).

The In vitro gas production was conducted in the Laboratory of Animal Nutrition, Center for Nuclear Energy in Agriculture, University of São Paulo (LANA/CENA/ USP), located in Piracicaba/São Paulo/Brazil. The donors of rumen fluid were three Santa Ines adult male sheep, provided with permanent rumen cannula. Donor animals were fed hay grass, concentrate, water and access to mineral mixture. The methodology consisted of a semi-automatic system of incubation of the diets kept in glass containers at $39^{\circ}$ Celsius for 24 hours using the methodology of Theodorou et al. (1994) adapted Bueno et al. (2005) and Longo et al. (2006). The total cumulative production of gas in the containers was quantified by reading the pressure of gas $(2,4,8,12$ and 24 hours after incubation). The methane production was determined by gas-cromatrography.

After 24 hours of incubation, the fermentation was interrupted with ice, the residue was washed with NDF solution, drying and filtration was performed to determine the true degradability of DM (TDDM) and OM (TDOM). The relationship between TDDM (mg) and the total gas production in 24 hours was used as index of microbial efficiency (PF: partition factor), following the methodology of Blummel, Makkar and Beckel (1997).
The variables were submitted to analysis of variance and regression tested for linear and quadratic models based on PROC GLM of SAS (2003), with significance level of $5 \%$ probability.

\section{RESULTS AND DISCUSSION}

The answers to the protein replacement of soybean meal by Crambe cake protein in the lamb diet followed linear models for all variables that had significant effects of treatments.

The increase on replacement of ingredients resulted in significant linear decreasing $(\mathrm{P}<0.05)$ for the ADC of DM, OM, EE, GE, ADF, NDF, CEL, TDN, and did not modify the ADC of CP, HEM, NFC, and NBal (Table 3).

The ADC of DM and OM were high due to the composition of the diets, with high proportion of non-fiber carbohydrates. The significant decrease in the ADC of $\mathrm{DM}$ and $\mathrm{OM}$ are result of decreased $\mathrm{ADC}$ of fiber fraction, especially cellulose (Table 2). Goes et al. (2010) evaluated in situ degradability of potentially degradable DM fraction and effective degradability of Crambe cake and soybean meal and found lower values for Crambe cake compared to soybean meal. Evaluation of apparent digestibility in sheep held by Hartwig, Kampf and Lebzien (2005) comparing Crambre cake and meal, found smaller values of OM digestibility and smaller intake for Crambe cake compared to Crambe meal. 
CANOVA, E. B. et al.

Table 3 - Apparent digestibility Coefficient (ADC in \%) of nutrients in diets.

\begin{tabular}{cccccccc}
\hline Variables & \multicolumn{4}{c}{ Treatments (\%) } & \multicolumn{3}{c}{ Effects } \\
\cline { 2 - 5 } & 0 & 22 & 44 & 64 & SEM & P>F & $\mathrm{R}^{2}$ \\
\hline ADCDM & 76.10 & 75.62 & 74.60 & 68.18 & 2.20 & 0.025 & 0.607 \\
ADCOM & 77.93 & 77.80 & 76.82 & 71.02 & 1.96 & 0.028 & 0.605 \\
ADCCP & 73.68 & 74.00 & 75.87 & 71.01 & 2.15 & 0.542 & 0.382 \\
ADCEE & 98.67 & 97.25 & 96.03 & 94.31 & 0.14 & $<.0001$ & 0.970 \\
ADCGE & 75.10 & 75.58 & 75.18 & 69.11 & 2.22 & 0.044 & 0.673 \\
ADCADF & 56.38 & 52.77 & 48.10 & 38.18 & 3.97 & 0.0032 & 0.715 \\
ADCNDF & 65.34 & 64.96 & 65.16 & 57.12 & 2.38 & 0.044 & 0.713 \\
ADCCEL & 69.24 & 66.83 & 63.63 & 57.62 & 2.57 & 0.0033 & 0.751 \\
ADCHEM & 74.12 & 75.92 & 76.69 & 68.12 & 3.08 & 0.250 & 0.247 \\
ADCNFC & 94.69 & 94.28 & 93.20 & 89.22 & 2.34 & 0.097 & 0.271 \\
\hline NBal (g/day) & 1.23 & 1.50 & 1.33 & 1.30 & 0.25 & 0.967 & 0.212 \\
TDN (\%) & 76.31 & 78.10 & 79.67 & 76.08 & 1.81 & 0.046 & 0.528 \\
\hline
\end{tabular}

SEM: standard error of the mean; $(\mathrm{P}<0,05)$; coefficient of determination $\left(\mathrm{R}^{2}\right)$.

The ADC of CP was not affected by the increase replacement of soybean meal protein by the Crambe cake protein, and denotes similar digestibility of both into the digestive tract.

Replacement of soybean meal protein by Crambe cake protein caused significant linear decrease in ADC of ADF, NDF and CEL due probably to the higher concentration of ADF and lignin in Crambe cake (Table 2). The ADC of hemicelluloses was not affected by the substitution of ingredients and means that lignocellulose fraction (ADF), especially cellulose, was that suffered the greatest effect of reduction of digestibility with the substitution of ingredients. It is known that the presence of lignin in ruminant diets increases the indigestible fraction, reduces the potentially digestible fraction and leads to decreased food intake and digestibility (Van Soest, 1994). In vitro evaluation conducted by Steg, Hindle and Liu (1994) with shelled and unshelled Crambe meal, demonstrated smaller values for shelled meal $(44.5 \%)$ compared to unshelled meal (85\%). Another factor that may have contributed to the decrease in apparent digestibility of fiber fraction was the high EE content of the diets, because the increase in levels of inclusion of Crambe cake in s caused increase in the level of EE (Table 1). It is known that the increase in oil in the diets of ruminants causes a reduction in the growth of bacteria and fibrolytic thereby decreasing the portion of the digestion of dietary fiber (Van Soest, 1994). According to the AFRC (1993), the presence of oils in the diet does not provide ATP for the growth of rumen microorganisms and thus high levels of EE may decrease the digestibility of the fiber.

The ADC of HEM and NFC diets were high and were not affected by the change of the protein ingredients of the diets (Table 3), because according to Hall (2003) these fractions have high ruminal degradability.

The values for the ADC were high EE and denote the proper use of this fraction by lambs. However, the increase in the substitution of Crambe cake was decreased to ADC of EE and GE, probably due to the greater amount of EE in feces as a result of increased intake of EE in diets with a higher proportion of Crambe cake (Table 2). The same could have caused the decrease of the TDN with increasing substitution of ingredients.

Replacement of soybean meal protein by the Crambe cake protein caused a significant linear decrease $(\mathrm{P}=0.0532)$ for the total daily DM intake (DMI) without alter $(\mathrm{P}>0.05)$ the intake in percentage live weight $(\%$ LW) and the intake per unit of metabolic weight (UMW) (Table 4). The value of DM intake is in agreement with the value suggested by the NRC (2007) for finishing lambs. It is noteworthy that the animals gained around $160 \mathrm{~g} /$ day during the trial period.

The regulation of food intake by ruminants is determined by physical factors (rumen fill) and/or chemical (energy level, amount of EE) (Forbes, 2007). The increased 
concentration of lignified fiber and the consequent decrease of the apparent digestibility of DM, OM and fibrous fractions, may have contributed to lower passage rate and a lower ruminal emptying, resulting in reduced diet intake. Crambe cake has high energy concentration due its high lipid content and for this reason may have contributed to the reduction of DM intake (Tables 1 and 2). According to Forbes (2007), diets with high EE content lead to cholecystokinin (CCK) hormone releasing, which is produced by endocrine cells in the gastrointestinal region, which control satiety.

Research conducted by Anderson et al. (1993), with increasing levels of Crambe cake replacing soybean meal in isonitrogenous diets for steers showed that soybean meal can be fully replaced by Crambe cake, without detriment to the weight gain, feed conversion and carcass characteristics.

The replacement levels of Crambe cake did not cause changes in the blood plasma parameters of AST and ALT $(P>0.05)$ of the animals (Table 5$)$. These results demonstrated that there was no liver damage by continued ingestion and the high amount of Crambe cake, during the evaluation in a period of 34 days, because according to (Kaneko; Harvey; Bruss, 2008), the values found in this experiment are below those that may cause liver damage.

The urea concentration was not affected by replacing the protein sources and means similarity in their ruminal degradation and utilization. The values found are lower than those found by Issakowicz et al. (2013), for lambs fed with high concentrate diets with soybean meal as protein ingredient.

The in vitro total gas production (Table 6) underwent significant linear decrease $(\mathrm{P}<0.05)$ with the replacement of soybean meal protein by Crambe cake protein, but there were no significant effect $(\mathrm{P}>0.05)$ for the partition factor (PF), as well as, for true degradability of DM and OM.

Decreased total gas production and methane may be due to the decreased fermentation of fiber, as seen in the decreased apparent digestibility coefficient of NDF, ADF and cellulose (Table 3). The increased levels of EE and lignin in the diets with higher Crambe cake are responsible for this fact. The inclusion of EE rich products in ruminant diet, as oilseed cakes, leads to smaller enteric methane production as found by Abdalla et al. (2008).

Research by Mizubuti et al. (2011) also found a decreased in vitro gas production of Crambe cake or meal in relation to soybean meal, which the authors attributed to the higher concentration of lignified fiber in those ingredients. In another study, the same authors compared in vitro fermentation of cottonseed or Crambe meals and observed that gas production was similar between them, because these foods exhibit similar fermentation patterns.

Table 4 - Average daily DM intake in grams (DMI), as percentage of live weight (\% LW) and as unit of metabolic weight (g/UMW).

\begin{tabular}{ccccccc}
\hline Variables & \multicolumn{4}{c}{ Treatments (\%) } & \multicolumn{2}{c}{ Effects } \\
\cline { 2 - 5 } & 0 & 22 & 44 & 64 & $\mathrm{P}>\mathrm{F}$ & $\mathrm{R}^{2}$ \\
\hline DMI (g) & $796 \pm 0.033$ & $727 \pm 0.033$ & $750 \pm 0.031$ & $687 \pm 0.031$ & 0.053 & 0.55 \\
\% LW & $3.35 \pm 0.16$ & $3.47 \pm 0.16$ & $3.41 \pm 0.15$ & $3.24 \pm 0.15$ & 0.570 & 0.40 \\
UMW & $74.04 \pm 3.12$ & $74.18 \pm 3.18$ & $73.75 \pm 2.97$ & $69.56 \pm 2.97$ & 0.309 & 0.31 \\
\hline
\end{tabular}

Unit of metabolic weight $=$ Live weigh ${ }^{0,75} ; \pm($ standard error of the mean $)$; coefficient of determination $\left(\mathrm{R}^{2}\right)$.

Table 5 - Biochemical parameters of blood alanine aminotransferase (ALT), aspartate aminotransferase (AST), Glucose and Urea.

\begin{tabular}{crrrrrl}
\hline Variables & \multicolumn{4}{c}{ Treatments (\%) } & \multicolumn{2}{c}{ Effects } \\
\cline { 2 - 5 } & \multicolumn{1}{c}{0} & \multicolumn{1}{c}{22} & \multicolumn{1}{c}{44} & \multicolumn{1}{c}{ P $>\mathrm{F}$} & \multicolumn{1}{c}{$\mathrm{R}^{2}$} \\
\hline ALT (IU/L) & $11.01 \pm 2.07$ & $9.51 \pm 2.07$ & $15.94 \pm 1.96$ & $9.77 \pm 1.96$ & 0.80 & 0.15 \\
AST (IU/L) & $74.04 \pm 8.98$ & $96.37 \pm 8.98$ & $80.31 \pm 8.54$ & $96.96 \pm 8.53$ & 0.22 & 0.24 \\
Glucose (mg/dL) & $84.15 \pm 9.71$ & $86.71 \pm 9.71$ & $74.45 \pm 9.23$ & $74.30 \pm 9.23$ & 0.31 & 0.098 \\
Urea (mg/dL) & $40.89 \pm 5.09$ & $31.19 \pm 5.09$ & $32.50 \pm 4.84$ & $30.00 \pm 4.84$ & 0.16 & 0.28 \\
\hline
\end{tabular}

\pm (standard error of the mean ), coefficient of determination (R2). 
Table 6 - Total gas production (TGP) and production of methane (CH4) in 24 hours, partition factor and true degradability of DM and OM.

\begin{tabular}{cccccccc}
\hline Variables & \multicolumn{4}{c}{ Trataments $(\%)$} & \multicolumn{3}{c}{ Effects } \\
\cline { 2 - 5 } & 0 & 22 & 44 & 64 & SEM & P $>$ F & $\mathrm{R}^{2}$ \\
\hline $\mathrm{TGP}(\mathrm{mL} / \mathrm{g} \mathrm{DM})$ & 287 & 287 & 281 & 275 & 2.39 & 0.0231 & 0.90 \\
$\mathrm{CH}_{4}(\mathrm{~mL} / \mathrm{g} \mathrm{DM})$ & 19.8 & 18.9 & 18.0 & 17.4 & 0.49 & 0.0029 & 0.95 \\
$\mathrm{CH}_{4}(\%)$ & 5.3 & 5.0 & 4.9 & 4.8 & 0.12 & 0.0056 & 0.94 \\
$\mathrm{PF}$ & 3.40 & 3.41 & 3.45 & 3.41 & 0.11 & 0.901 & 0.62 \\
$\mathrm{TDDM} \mathrm{g} / \mathrm{kg}$ & 860 & 903 & 861 & 797 & 44.90 & 0.843 & 0.73 \\
$\mathrm{TDOM} \mathrm{g} / \mathrm{kg}$ & 786 & 810 & 773 & 728 & 31.49 & 0.554 & 0.70 \\
\hline
\end{tabular}

SEM: standard error of the mean; ( $<<0.05$, coefficient of determination (R2).

The replacement of protein ingredients in lamb diets resulted in decreased in vitro gas production, without significantly affect the TDDM and TDOM. The relationship between fermented $\mathrm{OM}$ and gas production gives rise to the partition factor $(\mathrm{PF})$ that evidence microbial mass production. Higher PF values indicates that more organic matter is degraded and incorporated into microbial mass per $\mathrm{mL}$ of gas produced but, in reverse, lower PF value indicates higher gas production which is reflected in lower efficiency of fermentation process with increased production of $\mathrm{CO}_{2}$ and methane (Blummel; Makkar; Beckel, 1997). So Crambe cake and soybean meal are similar in this parameter, due to the significant decrease in gas production without altering the TDOM, and indicates that the microbial mass produced was similar among diets. The values of PF found in this study are within the range of 2.7 to $4.4 \mathrm{mg} \mathrm{TDOM} / \mathrm{mL}$ of gas produced as recommended by Makkar (2004).

\section{CONCLUSIONS}

Replacement of soybean meal protein by Crambe cake protein in high concentrate lamb diet leads to increased lignified fiber, which causes decreased DM digestibility, especially on fiber fraction, and leads to voluntary intake reduction. Crambe cake increases EE in diets which promote mitigation of methane without altering ruminal degradation. Crambe cake can be used for lambs, because assure a large energy and protein intake with similar protein characteristics to soybean meal.

\section{ACKNOWLEDGEMENTS}

To CNPq (National Council of Scientific and Technological Development/Brazil) for the scholarship and for financing this project (574172/2008-4).

\section{REFERENCES}

ABDALLA, A. L. et al. Methane production and microbial evaluation by q-PCR of in vitro incubations of tannin-rich plants. Microbial Ecology in Health and Disease. 19(1):32, 2007.

ABDALLA, A. L. et al. Utilização de subprodutos da indústria de alimentação de biodiesel para ruminantes.

Revista Brasileira de Zootecnia. 37:260-268, 2008.

AGRICULTURAL AND FOOD RESEARCH COUNCIL - AFRC. Energy and protein requirement of ruminants. Wallingford: CAB International, 1993. 159p.

ANDERSON, V. L. et al. Crambe meal is equivalent to soybean meal for backgrounding and finishing beef steers.

Journal of Animal Science. 71(10):2608-2613, 1993.

BLUMMEL, M., MAKKAR, H. P. S., BECKEL, K. In vitro gas production: technique revisited. Journal of Animal

Physiology and animal nutrition. 77(1):24-34, 1997.

BUENO, I. S. et al. Influence of inoculum source in a gas production method. Animal Feed Science and Technology.123-124:95-105, 2005.

FORBES, J. M. Voluntary food intake diet selection in farm animals. 2.ed. Cambridge: $\mathrm{CAB}$ International, 2007. 453p.

GOES, R. et al. Degradabilidade in situ dos grãos de Crambe, girassol e soja, e de seus coprodutos em ovinos. Acta Scientiarum. Animal Sciences. 32(3):271-277, 2010. 
GRAINGER, C. Methane: increasing fat can reduce methane emissions. Newsletter. Department of Primary Industries. GIA Newsletter, 10(3) p.5, 2008.

HALL, M. B. Challenges with nonfiber carbohydrate methods. Journal of Animal Science. 81:3226-3232, 2003.

HARTWIG, B.; KAMPF, D.; LEBZIEN, P. Feeding value of Crambe press cake and extracted meal as well as production responses of growing-finishing pigs and dairy cows fed these by-products. Archives of Animal Nutrition. 59(2):111-122, 2005.

ISSAKOWCZ, J. et al. Effect of concentrate level and live yeast (Saccharomyces cerevisiae) supplementation on Texel lamb performance and carcass characteristics. Livestock Science. 1:44-52, 2013.

KANEKO, J.J.; HARVEY, J.W.; BRUSS, M.L. Clinical biochemistry of domestic animals. 6.ed. New York: Academic Press, 2008. 928p.

LONGO, C. et al. The influence of head space and inoculums dilition on vitro ruminal methane measurements. International Congress Series. 1223:62-65, 2006.

MAKKAR, H. P. S. Recent advances in the in vitro gas method for evaluation of nutritional quality of feed resources. In: Assessing Quality and Safety of Animal Feeds. FAO Animal Production and Health Series. Rome, p. 55-88, 2004.

MIZUBUTI, I. Y. et al. Cinética de fermentação ruminal in vitro de alguns co-produtos gerados na cadeia produtiva do biodiesel pela técnica de produção de gás. Ciências Agrárias. 32:2021-2028, 2011.

NATIONAL RESEARCH COUNCIL - NRC. Nutrient Requirement of Sheep. Washington, DC: National Academic Press, 2007. 99p.

STEG, A.; HINDLE, V.A.; LIU, Y. G. By-products of some novel oilseeds for feeding: laboratory evaluation. Animal Feed Science and Technology. 50(1-2):87-99, 1994.

THEODOROU, M. K. et al. A simple gas production method using a pressure transducer to determine the fermentation kinetic of ruminant feeds. Animal Feed Science and Technology. 48(3):185-197, 1994.

TRIPATHI, M. K; MISHRA, A. S; Glucosinolates in animal nutrition: A review. Animal Feed Science and Technologic. 132(1-2):1-27, 2007.

VAN SOEST, P.J. Nutritional Ecology of the Ruminant. 2. ed. Ithaca: Cornell University Press, 1994. 476p. 